\title{
REAL EFFECTIVE EXCHANGE RATE AND INDUSTRIAL PRODUCTIVITY IN CROATIA: WAVELET COHERENCE ANALYSIS
}

Mile Bošnjak, Gordana Kordić, Ivan Novak

\section{Abstract}

This paper brings releationship between real effective exchange rate and industry production in Croatia. Research sample consists of monthly data from January 2000 up to June 2019. Following wavelet coherence approach, empirical results reveal the relationship across time and frequency domain. The empirical obtained from wavelet coherence analysis and confirmed with conventional correlation analysis suggested positive relationship between industrial productivity and real effective exchange rate in Croatia, with depreciation as a factor of positive influence on industrial productivity. Research results provided in the paper also contributes to the debate on exchange rate policy in Croatia, extending the discussion on national exchange rate policy implications.

Keywords: real effective exchange rate, industrial productivity, wavelet coherence analysis, Croatia.

JEL Classification: E52, F31

\section{INTRODUCTION}

There is a strong research interest on the interrelation of real effective exchange rate and industrial productivity, resulting also in discussion on the optimality of a chosen exchange rate regime and equilibrium exchange rate against the most important trading partners. Furthermore, there is a wide body of literature on the connections between real effective exchange rate and different aspects of economic performance, including export growth, industrial productivity, competitiveness, etc. It is important to notice, since the paper is examining the croatian case, that the institution which is exclusively responsible for monetary policy and, consequently, exchange rate policy is Croatian National Bank (CNB). CNB is a fully independent institution while exchange rate regime is de jure defined as managed floating (with no officially pronounced bands), that is also referred as dirty floating, with price stability as its main goal. The exchange rate policy in Croatia has been stabile during the whole period since

Mile Bošnjak, PhD (corresponding author)

Assistant Professor

Faculty of Economics and Business Zagreb

University of Zagreb

Address:Trg J F. Kennedyja 6, 10000 Zagreb, Croatia e-mail: mile.bosnjak76@gmail.com

ORCID: 0000-0002-7663-198X

Gordana Kordić, PhD

Full Professor

Department of Finance, Faculty of Economics and Business Zagreb

University of Zagreb

e-mail: gkordic@net.efzg.hr

ORCID: 0000-0002-1914-2784

Ivan Novak, $\mathrm{PhD}$

Assistant Professor

Faculty of Economics and Business Zagreb

University of Zagreb

e-mail: inovak@efzg.hr

ORCID: 0000-0003-1473-7049 
independence, relying on deutsch mark/euro as exchange rate anchor. Putting stability in a first place, in connection with previously described limitations, results in a policy based on a rule and oriented towards fulfillment the goal, with generally less developing potential. Such stability oriented policy, with small fluctuations of exchange rate, does not develop a full stimulating potential for national industry competitiveness. Central and Eastern European countres generally has experienced deindustrialisation and a need of boosting coompetitivnes has been already recognised (Stojčić and Aralica 2018). That is why the industrial productivity, including the causes and consequences of deindustralisation and reindustralisation atrracts interest of researchers. As highlighted in aforementioned paper, there are weak evidence on the success of the old approach based on free market development and foreign direct investments and export sophistication with product space clustering might be a preffered strategy. As a result of central planning Popov (2019) found inherited distortions in industrial structure and interregional trade patterns. After the opening of national economies, high tech and secondary manufaturing industries that prevailed in the observed countries, were incompetitive which lowered their output. Further, the author concludes that the most effective ways to develop industry is to undervaluate exchange rate and increase public investments in areas of education and infrastructure. Undervaluated exchange rate should contribute to the export competitiveness of tradable goods, and such policy has been succesfully used so far (for example in East-Asia countries).

However, the role of real effective exchange rate for production development in Croatia has been uderexamined. To overcome the existing gap in litarature this paper makes a step ahed. The reminder of the paper is organised as follows: section 2 focuses on brief summary of the existing literature. Section 3 further describes research data and methodology, while section 4 provides empirical results and discussion. Finally, last section gives a research conclusion, including the overview of the main findings.

\section{LITERATURE OVERVIEW}

Researh findings from literature related to the issue under consideration pointed out the existence of interrelation between excange rate and industrial productivity. Čizmović et al. (2021) analysed the relationship between real effective exchange rate and industrial production in terms of deindustrialisation or reindustralisation in 25 Eastern European countries.
Based on the heterogenous panel common approach used on time span 1995-2018 the authors concluded that the impact of real effective exchange rate depreciation is lower for countries with more complex economic systems that stronger participate in global value chains. Basarac Sertić et al. (2015) used panel data analysis in order to detect the determinants of exports for manufacturing industry in EU member states. Real effective exchange rate and industrial production are variables of interest, together with domestic and foreign demand, labour costs and economic crisis, assuming that the depreciation of real effective exchange rate will have a positive impact on exports, by lowering the prices.

Cuestas et al. (2019) analysed a sample of Central and Eastern European countries, focusing on real exchange rates and competitiveness. Authors investigated real effective rate fundamentals and theirs' longrun interconnection with real exchange rate, adding both supply- and demand-side effects. Research also included capital inflows into the analysis, confirming their positive influence on competitiveness, concluding that more emphasis should be on those factors that contribute to depreciation. Hence, as capital inflows reduced the prices that, cosequently, resulted in depreciation. Comunale (2017) studied real effective exchange rate misalingnments on GDP growth in EU focusing on its asymmetry. Research was based on a panel of 27 EU countries during 1994-2012 time span with annual frequency. The paper concluded that real effective exchange rate in new member states has been overvalued, while misalignments were associated with GDP growth. Ito and Shimizu (2015) developed their research of industry-level export competitiveness on unit labour costs and nominal effective exchange rates in period 2001-2009 for Japan, China and Korea. They confirmed the rise of relative prices as a result of the higher unit labor costs and exchange rate appreciation, with the highest impact of appreciation for Japan. Still, the effects differ between countries and industries that, the authors conclude, also depend on market power and non-price competitiveness. Based on the same set of countries and their producer price indices during Jan2001-Feb2013 time span, Sato et al. (2013) constructed a dataset of an industry specific real effective rate in order to explore the connection between exporters' competitivenesses. Results, based on the vector autoregression model, indicated that there is a significant impact of industry differences of cost competitiveness and changes in nominal exchange rates on exports in Japan and Korea. Rajput and Jain (2014), focusing on the case of India from 2004 (April) to 2013 (September) confirmed the relationship between real effective exchange rate 
and merchandise exports. Using different estimation techniques authors concluded that the increase in real effective exchange rate has adverse effect on exports, resulting in its decrease, measured in dollars. The case of non-financial firms in India has been in focus in Sikarwar (2014) leading to a confirmation of losses in terms of appreciation of national currency. Fornero et al. (2020) focused on the case of Chile, concluding that the influence of foreign demand on manufacturing exports was stronger than those arising from the exchange rate change. Wong (2019) contributes to the research of the effects of exchange rate misalignments, using autoregressive distibuted lag (ARDL) approach on the example of Malaysia, concluding that undervaluation has a positive impact on manufacturing sector. Inversely, influence of overvaluation is proven to be negative. Furthermore, the period of fixed exchange rate had a negative impact on national economy, while weakening of the regime had a positive impact. Zhang (2018) used a panel vector autoregression (VAR) approach in order to research the response of sectoral exports in Japan on exchange rate shocks, considering financial constraints. Results revealed that the response in the japanese case has been significant and negative. Internal and external financial constraints, though, significantly contributed. Exports would benefit only from the easing of internal and external constraints at the same time.

Discussions on the (over)valued exchange rate in Croatia and the influence of exchange rate on industrial productivity (and, consequently, economic growth) has been in place for the past few decades, since obtaining monetary independence. In earlier literature, Vukšić (2006) analysed the export performance of croatian manufacturing industry, primary in terms of foreign direct investments, also including the discussion on overvalution of national currency in his analysis. Tkalec and Vizek (2009) used quarterly data 1998Q1-2008Q3 aiming to expore the impact of macroeconomic policies on manufacturing production, considering 22 manufacturing sectors. Among other examined factors, the effect of real effective exchange rate found to be significant for low technological intensity industries. Dumičić et al. (2011) use linear regression model in order to measure depreciation effects on croatian economy, considering the competition effect and the wealth effect. Benazić and Tomić (2014) include exchange rate in their discussion on coordination between croatian monetary and fiscal policy. Authors tested the hypothesis of monetary and fiscal policy coordination in Croatia, finding numerous internal (exchange rate stability, fiscal austerity) and external (Maastricht criteria, Fiscal Stability Treaty) limitations to their efficiency, although they found them to be counter-cyclical but with relatively weak correlation with real GDP. Still, some fine-tuning actions might have reverse and destabilising effects on national economy.

Pavlić et al. (2015) also focused on the case of Croatia, empirically (Johansen Maximum Likelihood cointegration) investigating the relationship between tourism, real effective exchange rate and economic growth, based on 1996-2013 quarterly data. Using cointegration analyses, ADF, PP and KPSS tests, Johansen cointegration test and VECM model authors indicated (among other factors) both short- and longterm causality between real effective exchange rate and GDP as a dependent variable. The paper highlights the importance of tourism as a part of export on croatian economy, but also research its influence on exchange rate movements, detecting real effective exchange rate as a significant factor of tourism industry competitiveness. Tomić (2016) contributes to the discussion on (possible) misalignment of exchange rate in Croatia, discussing the terms of trade and confirming the S-curve hypothesis. The S-curve concept has been used to analyse the trade dynamics in Croatia, contributing to the research of impact of currency depreciation on trade balance. Further evaluation resulted in a conclusion that exchange rate changes would cause stronger negative consequences on debt and economic than positive effects on trade balance and international competitiveness. Bošnjak (2018) indicated the phenomenon of financial euroisation as a constraint to monetary policy in Croatia, but also for its economy and competitiveness. The research concluded that, in order to resolve this problem, there is a need for overall macroeconomic stability, not just the stability of exchange rate. As described in further detail in Stojčić (2012), the concept of competitiveness is rather complex, since it includes different indicators and measures, while exchange rate is one of the factors of influence.

\section{RESEARCH DATA AND METHODOLOGY}

Researh data consists of monthly data for real effective exchange rate against 19 eurozone member countries and industrial productivity (category C), covering the period from January 2000 till June 2019. The data for real effective exchange rate against 19 eurozone member countries were retreived from Eurostat while the data for industrial production index were obtaine for Croatian Beureau of Statistics. Development of industrial productivity and real effective exchange rate (REER) is presented in Figure 1. in the Appendix, while descriptive statistics is summarised in Table 1. in the 
Appendix. Increase in REER index is a sign of real depreciation, and the opposite, decrease is a sign of real appreciation.

Wavelet coherence approach provides observations in time and frequency domain that makes a further step from the conventional approaches of time series. For the purpose of the research provided in this paper, we started with the Morlet wavelet as in equation (1) that enables us to determine time dependent amplitude and phase for different frequencies.

$\psi^{M}(t)=\frac{1}{\pi^{\frac{1}{4}}} e^{i \omega_{0} t} e^{\frac{-t^{2}}{2}}$

In equation (1) the marks are as follows: $t$ represents time, while $\omega_{0}$ is a central frequency of a number of oscillations. The later are limited to six, as in economic studies provided in literature (Vacha and Barunik 2012). A wavelet approach allows valuable insights in co-movements between variables in time as well as in frequency domain.

Using equation (2) we provide continuous wavelet transform:

$W_{x}(\tau, s)=\frac{1}{\sqrt{s}} \int_{-\infty}^{\infty} x(t) \overline{\psi\left(\frac{t-\tau}{s}\right)} d t$

In equation (2), $x(t)$ stands for the time series observed, $s$ is the scale, while $\tau$ represents location, determining the position of the wavelet. Observed time series $x(t)$ is then decomposed in terms of wavelets. Then, the size and significance of correlation between industrial productivity and real effective exchange rate are observed as two time series.

Equation (3) is used to calculate the cross wavelet transformation of two time series $x(t)$ and $y(t)$

$W_{x y}(\tau, s)=W_{x}(\tau, s) \overline{W_{y}(\tau, s)}$

Continuous wavelet transformation of the observed time series $\mathrm{x}(\mathrm{t})$ is presented with $\mathrm{W}_{\mathrm{x}}(\tau, \mathrm{s})$ while $\overline{W_{y}(\tau, s)}$ represents complex conjugate continuous wavelet transform for time series $\mathrm{y}(\mathrm{t}) .\left|W_{x y}(\tau, s)\right|$ is the cross wavelet power.

The squared wavelet coherent coefficient is given in equation (4):

$$
R^{2}(\tau, s)=\frac{\left|s\left(s^{-1} W_{x y}(\tau, s)\right)\right|^{2}}{S\left(s^{-1}\left|W_{x}(\tau, s)\right|^{2}\right) S\left(s^{-1}\left|W_{y}(\tau, s)\right|^{2}\right)}
$$

in which $S$ represents a smoothing operator that is within the range from zero to one (similarly to the
Pearson squared correlation coefficient). Still, wavelet coherence analyses includes also phase differences between time series under consideration that is provided in equation (5):

$\varphi(\tau, s)=\tan ^{-1}\left(\frac{\Im\left(W_{x y}(\tau, s)\right)}{\Re\left(W_{x y}(\tau, s)\right)}\right)$

In the equation (5), $\Re$ represents the real part, while $\mathfrak{I}$ represents imaginary part of the cross wavelet transformation, as presented in equation (3).

In wavelet coherence analyses arrows represent phase difference. When time series are positively correlated and move together it is considered a zero phase difference. Positive correlation is presented when arrows pointed right and, on the contrary, arrows pointed left indicate negative correlation. Furthermore, arrows pointing up means that the first time series leads the second by the right angle. Arrows pointing down indicate that the second time series leads the first by the right angle. It should also be noted that these are the corner cases, while the position of arrows might indicate a combination of these two positions.

\section{EMPIRICAL RESULTS AND DISCUSSION}

Besides aforementioned research data and methodology, we have also analyzed Pearson Correlation coefficient and p-values.

Table 2. Pearson Correlation coefficient: estimate and test

\begin{tabular}{|l|c|}
\hline \multicolumn{2}{|c|}{ Pearson Corr. coefficient $=0.5233248$} \\
\hline$t=9.3542$ & $p$-value $<2.2 \mathrm{e}-16$ \\
\hline
\end{tabular}

Source: own estimations

Following the results obtained and presented in Table 2 we confirm positive and statistically significant correlation between REER and industrial productivity in Croatia.

The wavelet coherence is presented in Figure 2.

The wavelet coherence identifies the co-movement of industrial productivity and real effective exchange rate during the period observed. Horizontal axis covers the time period of research, while vertical axis shows the scale in manner that frequency is higher on lower points of the scale. As presented on the righthand scale, dark red colored regions indicate stronger correlation, while blue-colored area marks weaker 
Figure 2. - Wavelet coherence: industrial productivity vs. REER: case of Croatia

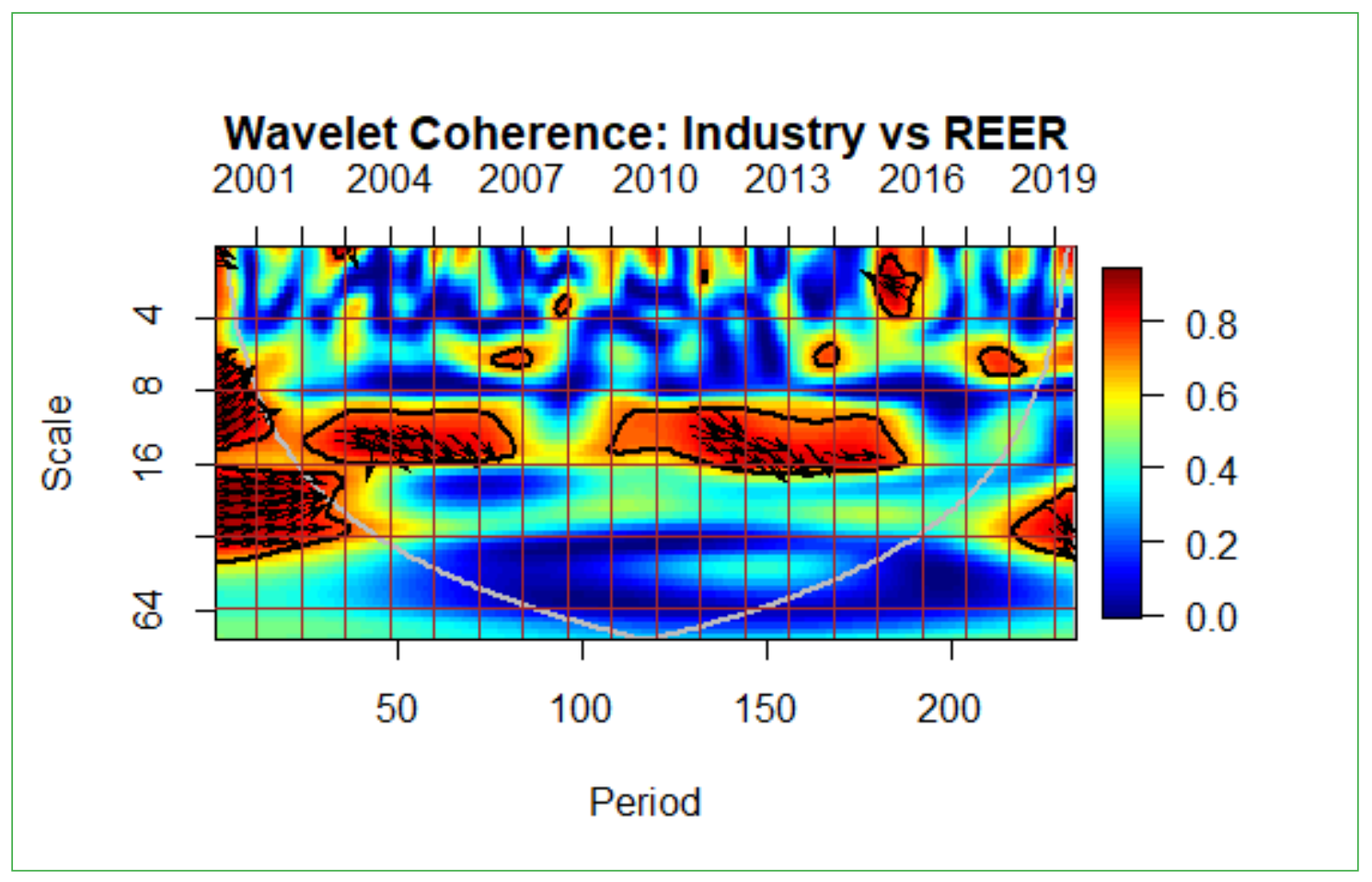

Source: own estimations

correlation between the observed variables. Longterm correlation is presented in higher scales while, on the contrary, lower scales indicate short-term correlation. Furthermore, as described above, an arrow in figure points to the leading or lagging role of the variable in co-movements of the two variables. Arrows pointing to the right indicate positive correlation and since the arrows are pointing down that puts the real effective exchange rate depreciation as the leading variable in Croatia. In that case, there has been a positive correlation between the two variables (depreciation of REER leads to growth in industrial productivity). Outside the bounded region the significance level is $5 \%$ that makes them non-significant.

Analyzing the time span, the correlation was strong between 2002-2007 and 2010-2015, while significant and high correlations were observed at middle scales, between 8 and 16. Depreciation of real effective exchange rate resulted in industrial productivity growth. On the contrary, from 2000-2003 arrows are pointing to the right and up, indicating that the leading variable is industrial productivity. During the 2007-2010, covering the period of global financial crisis, the model did not found any significant relationship while the correlations for the period after 2015 did not last longer than two years.
Conclusively, research results clearly point out the role of the real effective exchange rate in development of the Croatian industry and real depreciation of Croatian kuna makes Croatian industry product more competitive in term of prices. Recalling the results from Bošnjak (2018) among others, there is a prominent financial euroisation in Croatian financial system limiting the space for nominal depreciation of Croatian kuna against euro. The other possibility to influence price competitiveness would be management inflation but it seems as a second goal of monetary authorizes (Mance et al. 2015). Furthermore, Croatia has been EU member country since the 2013 and Bošnjak et al. (2019) illustrated convergence of import prices between Croatia and EMU members. Nonetheless, Croatia is on its path to the EMU and proper selection of exchange rate level at point of joining EMU might play a role. As suggested in Stojčić and Aralica (2018) there is a need to improve competitiveness of industry production in Croatia. Results from this paper sugest that real effective exchange rate ssould be included in policy mix aimed to improve industry performance and its competitivenes. 


\section{CONCLUSION}

The analyses presented in the paper is focused on real effective exchange rate movements and interrelation with industrial productivity in Croatia. It highlights the complexity of the national competitiveness and variables that might be used to improve it, considering the discussions on exchange rate policy that has been the question of interest in Croatia for past decades. Although the factors that influence processes and performance of Croatian industry has been researched from many aspects, the paper makes a step ahead in researching the role of REER across time and frequency domain.

There are several conclusions that can be obtained based on the empirical research provided in the paper. As presented in comparative studies in literature reviewed in this paper, there is a strong link between (real effective) exchange rate and industrial productivity. Analyzed literature indicated that exchange rate misalignment in terms of appreciation has a negative impact on national economy. Still, on national level, examining the Croatian case, there are limitations on depreciation of national currency, such are previous hyperinflations, high levels of unofficial euroisation, European integration convergence criteria, etc.

Both the conventional approach and the wavelet coherence analyses confirmed mostly positive interrelation between industrial productivity and real effective exchange rate in Croatia. The depreciation in real effective exchange rate was positively correlated with industrial productivity during the period observed. While examining the co-movement between real effective exchange rate and industrial production, real exchange rate unambiguously appeared as the leading variable. Based on the results from research presented in this paper, real depreciation of Croatian kuna could improve price competitiveness of Croatian industry products and boost the industry development in Croatia. However, there are constraints arising from financial sector rooted in high level of financial euroization. Further research should be directed towards finding non-price competitiveness of Croatian industry. The findings might also help the policy makers during the accession process to the European monetary union, in terms of better preparation for full (monetary and economic) integration on single market.

Further research should also include determination of country-specific factors influencing industrial productivity on one side and real effective exchange rate on the other. Role of external shocks should be considered too, including also the changes in exchange rate policy arising from the membership in ERM II and the crisis of global economy caused by the corona virus.

\section{REFERENCES}

Basarac Sertić, M., Vučković, V. and Škrabić Perić, B. 2015. Determinants of manufacturing industry exports in European Union member states: a panel data analysis. Economic research-Ekonomska istraživanja, 28(1), 384397., https://doi.org/10.1080/1331677x.2015.1043781

Benazić, M. and Tomić, D. 2014. The evaluation of fiscal and monetary policy in Croatia over a business cycle. Zbornik radova Ekonomskog fakulteta u Rijeci: časopis za ekonomsku teoriju i praksu, 32(1), 75-99.

Bošnjak, M. 2018. Financial eurization in Croatia and its (non) linear pattern behaviour. Croatian Operational Research Review, 9(1), 51-62., https://doi.org/10.17535/crorr.2018.0005

Bošnjak, M., Bilas, V. and Račić, D. 2019. Time-varying parameters of Croatian import demand. Zbornik radova Ekonomskog fakulteta u Rijeci: časopis za ekonomsku teoriju i praksu, 37(2), 853-872.

Čizmović, M., Shachmurove, Y. and Vulanović, M. 2021. Real Effective Exchange Rates and deindustrialization: Evidence from 25 Post-Communist Eastern European countries. Post-Communist Economies, 1-37., doi:10.10 80/14631377.2020.1867429

Comunale, M. (2017). Dutch disease, real effective exchange rate misalignments and their effect on GDP growth in EU. Journal of International Money and Finance, 73, 350-370., https://doi.org/10.1016/j.jimonfin.2017.02.012

Cuestas, J., Monfort, M. and Ordóñez, J. 2019. Real exchange rates and competitiveness in Central and Eastern Europe: have they fundamentally changed? (No. 2019/12)., Working Papers, Universitas Jaume I, Spain, available at http://www.doctreballeco.uji.es/wpficheros/Cuestas et al 12 2019.pdf, [January 27th 2020]

Dumičić, K., Palić, I. and Šprajaček, P. 2011. Procjena učinaka konkurentnosti i bogatstva kao posljedica promjene realnog deviznog tečaja na hrvatsko gospodarstvo. Zbornik Ekonomskog fakulteta u Zagrebu, 9(2), 35-52.

Fornero, J. A., Fuentes D. M. A. and Gatty Sangama, A. 2020. How do manufacturing exports react to the real exchange rate and foreign demand? The Chilean case. The World Economy, 43(1), 274-300., https://doi.org/10.1111/twec.12891

Ito, K. and Shimizu, J. 2015. Industry-Level Competitiveness, Productivity and Effective Exchange Rates in East Asia. Asian Economic Journal, 29(2), 181-214., https://doi.org/10.1111/asej.12054

Mance, D., Žiković, S. and Mance, D. 2015. Econometric Analysis of Croatia's Proclaimed Foreign Exchange Rate. South East European Journal of Economics and Business, 10(1), 7-17. https://doi.org/10.1515/jeb-2015-0001

Pavlić, I., Svilokos, T. and Šuman Tolić, M. 2015. Tourism, real effective exchange rate and economic growth: Empirical 
evidence for Croatia. International Journal of Tourism Research, 17(3), 282-291., https://doi.org/10.1002/jtr.1986

Popov, V. 2019. Successes and failures of industrial policy: Lessons from transition (post-communist) economies of Europe and Asia., MPRA Paper No. 95332, https://mpra. ub.uni-muenchen.de/95332/ (January 13th, 2021)

Rajput, N. and Jain, S. 2014. Effect of REER on exports: An anecdote from India. International Journal of Management, IT and Engineering, 4(6), 154-168

Sato, K., Shimizu, J., Shrestha, N. and Zhang, S. 2013. Industryspecific Real Effective Exchange Rates and Export Price Competitiveness: The Cases of Japan, China, and Korea. Asian Economic Policy Review, 8(2), 298-321., https://doi.org/10.1111/aepr.12032

Sikarwar, E. 2014. A re-examination of exchange rate exposure: Industry-level analysis of Indian firms. Global Business Review, 15(4), 867-882., https://doi.org/10.1177/0972150914543416

Stojčić, N. 2012. Theoretical foundations and measurement of competitiveness. Poslovna izvrsnost: znanstveni časopis za promicanje kulture kvalitete i poslovne izvrsnosti, 6(2), 143-165.

Stojčić, N. and Aralica, Z. 2018. (De) industrialisation and lessons for industrial policy in Central and Eastern Europe. Post-communist economies, 30(6), 713-734., https://doi.org/10.1080/14631377.2018.1443251
Tkalec, M. and Vizek, M. 2009. The impact of macroeconomic policies on manufacturing production in Croatia. Privredna kretanja i ekonomska politika, 19(121), 61-93.

Tomić, D. 2016. An alternative approach to the trade dynamics in Croatia. Journal of Economic and Social Development, 3(2), 16.

Vacha, L. and Barunik, J. 2012. Co-movement of energy commodities revisited: Evidence from wavelet coherence analysis. Energy Economics, 34(1), 241-247., https://doi.org/10.1016/j.eneco.2011.10.007

Vukšić, G. 2006. Impact of Foreign Direct Investment on Croatian Manufacturing Exports. Occasional Paper Series-Institute of Public Finance, (27), 5.

Wong, H. T. 2019. Real exchange rate misalignment and economy. Journal of Economic Studies, 46(1), 211-227., https://doi.org/10.1108/jes-07-2017-0181

Zhang, S. 2018. Industry-specific Exchange Rate Fluctuations, Japanese Exports and Financial Constraints: Evidence from Panel Vector Autoregressive Analysis. Asian Economic Journal, 32(2), 125-145., https://doi.org/10.1111/asej.12145 
Figure 1. Industrial productivity and REER development, case of Croatia

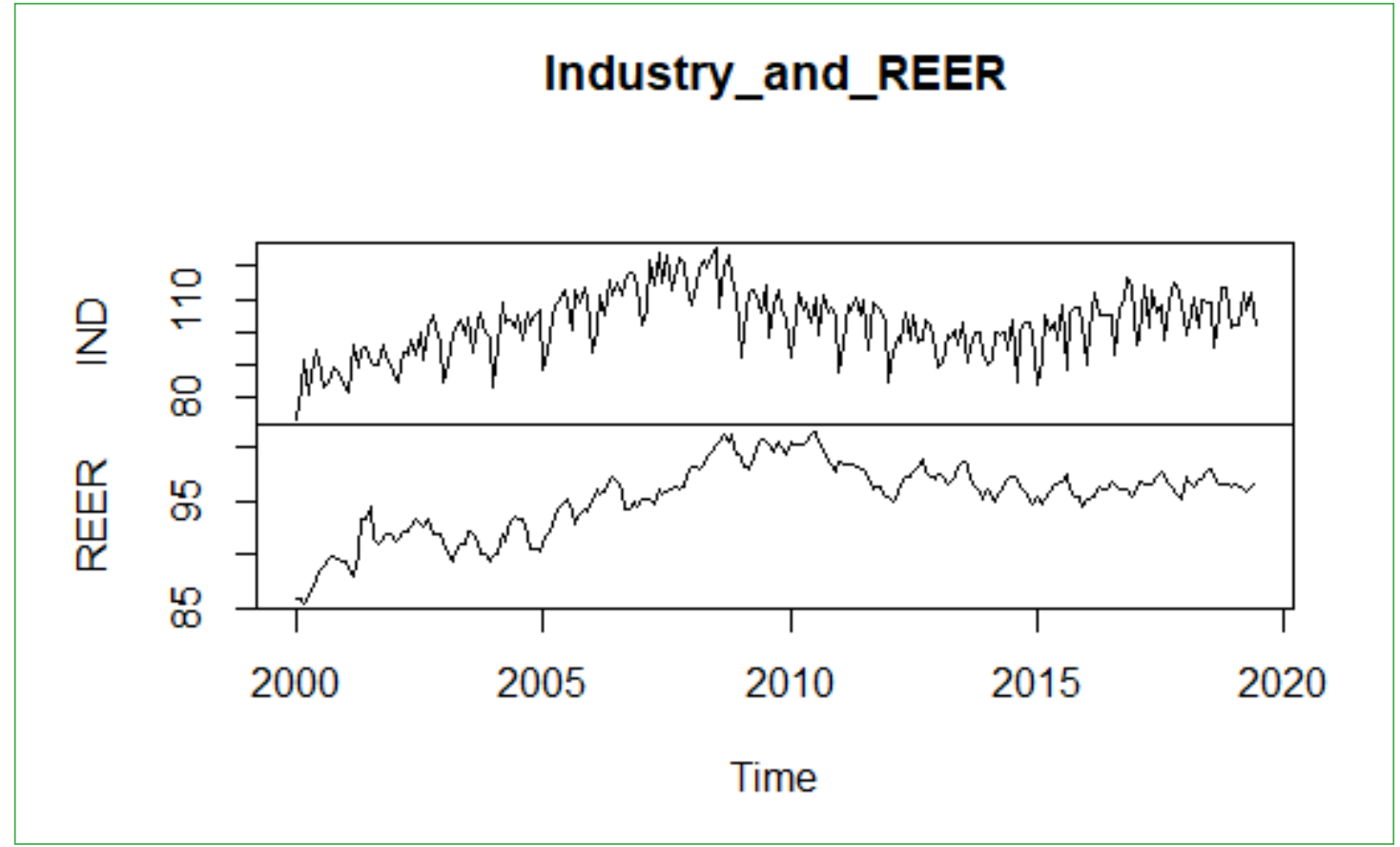

Source: authors

Table 1. Descriptive statistics for industrial productivity and REER, case of Croatia

\begin{tabular}{|l|c|c|}
\hline & IND & REER \\
\hline Min. & 73.40 & 85.55 \\
\hline 1st Qu. & 95.75 & 93.33 \\
\hline Median & 102.85 & 96.14 \\
\hline Mean & 102.51 & 95.36 \\
\hline 3rd Qu. & 109.28 & 97.38 \\
\hline Max. & 125.40 & 101.46 \\
\hline
\end{tabular}

Source: own estimations 